\title{
Plasma biochemistry, gene expression and liver histomorphology in common carp (Cyprinus carpio) fed with different dietary fat sources
}

\author{
P. Eljasik ${ }^{a, *}$, R. Panicz ${ }^{\mathrm{a}}$, M. Sobczak ${ }^{\mathrm{a}}$, J. Sadowski ${ }^{\mathrm{b}}$, V. Barbosa ${ }^{\mathrm{c}}$, A. Marques $^{\mathrm{c}}$, J. Dias ${ }^{\mathrm{d}}$ \\ ${ }^{a}$ Department of Meat Science, Faculty of Food Science and Fisheries, West Pomeranian University of Technology, 71-550, Szczecin, 4 Kazimierza Królewicza Street, Poland \\ ${ }^{\mathrm{b}}$ Department of Aquatic Bioengineering and Aquaculture, Faculty of Food Science and Fisheries, West Pomeranian University of Technology, 71-550, Szczecin, 4 \\ Kazimierza Królewicza Street, Poland \\ ${ }^{\mathrm{c}}$ Divisão de Aquacultura, Valorização e Bioprospecção. Instituto Português do Mar e da Atmosfera, I.P. Lisboa. Portugal, Avenida Professor Doutor Alfredo Magalhães \\ Ramalho 6, 1495-165, Algés, Portugal \\ ${ }^{\mathrm{d}}$ Sparos Lda, Área Empresarial de Marim, Lote C, 8700-221, Olhão, Portugal
}

\section{A R T I C L E I N F O}

\section{Keywords:}

EPA and DHA

Fat metabolism

Fish fortification

Hepatocyte histomorphology

Lipid-dependent genes

Schizochytrium

\begin{abstract}
A B S T R A C T
Demand for omega-3 long chain polyunsaturated fatty acids has become global challenge for aquaculture and different components have been used to increase nutritional value of fillets. The aim of this study was to evaluate influences of feeds on zootechnical parameters, biochemical plasma parameters, expression of lipid-dependent genes, hepatocyte histomorphologies, and fatty acid profiles in common carp fillets. We compared a control diet (CTRL), mimicking a commercial feed formulation for common carp, with three diets containing blends of vegetable oils and a DHA-rich alga (Schizochytrium sp.) included at 3.125\% (CB1) or 1.563\% (CB2), and 2.1\% salmon oil (CB3). The study revealed no differences in final body weight of fish fed CB1-3 diets in comparison with significantly lower CTRL. Concentrations of all biochemical parameters in plasma increased gradually in fish fed CB1-3 diets when compared to CTRL diet, with exception of triacylglycerol levels. Expression of hepatic fas, elovl-5a and ppara genes increased significantly in fish fed CB1 and CB2. Additionally, eicosapentaenoic (EPA) and docosahexaenoic acid (DHA) accumulation in muscle tissue was directly proportional to the amounts supplied in the diets. Our study revealed that carp fillet profiles can be manipulated for DHA and EPA-contents using enriched diets, depending on the source of fat.
\end{abstract}

\section{Introduction}

The essential role of omega- 3 polyunsaturated fatty acids (n-3 PUFAs) in human nutrition has been studied widely in recent years (EFSA, 2014). The n-3 PUFAs functions in neurogenesis, neurotransmission, protection against oxidative stress, and are particularly important during brain development (Innis, 2007). Moreover, they are components of cell walls, determining fluidity, elasticity and permeability, and have beneficial effects against development of various human conditions, such as inflammation and autoimmune, cardiovascular and neurodegenerative diseases (Arts and Kohler, 2009; Liu and Ma, 2014; Zhang et al., 2019). The recommended daily intakes for eicosapentaenoic (EPA) and docosahexaenoic (DHA) acids (recommended by national and international authorities $-250 \mathrm{mg} /$ day) is achieved by only $26 \%$ of Europeans (Sioen et al., 2017).

A good source of n-3 fatty acids in human diets is fish, specifically marine fish. Generally, EFA (essential fatty acid) contents of freshwater fish is lower, and dependent on physico-chemical parameters of their habitat, season and geographical location as well as physiology (Williams et al., 2017). Freshwater fish fillets are more susceptible to changes in dietary fatty acid (FA) profile, i.e. ingredients in new feed blends. For example, fillets from Nile tilapia (Oreochromis niloticus) fed increased proportions of fish oil (FO) in an experimental diet had contained more DHA and EPA compared with fish fed a control diet (Özlüer Hunt et al., 2018). A comparable observation has been described for Atlantic salmon (Salmo salar) (Sissener, 2018). This supports the rational of utilizing sustainable raw materials rich in PUFAs for feed production. Decreasing availability and growing costs associated with animal ingredients rich in PUFAs has forced producers to consider plant-based ingredients (e.g. rapeseed oil, sunflower oil), insects (e.g. black soldier fly larvae meal), microalgae (e.g. Schizochytrium sp. meal) and by-products from fish processing (e.g. salmon meal). However, new implemented ingredients are potentially hazardous, because may include a range of contaminants, like heavy metals, mycotoxins, pesticide

\footnotetext{
* Corresponding author. Department of Meat Science, Faculty of Food Science and Fisheries, West Pomeranian University of Technology, Kazimierza Królewicza 4, 71-550, Szczecin, Poland.

E-mail address: peljasik@zut.edu.pl (P. Eljasik).
} 


\author{
Abbreviations \\ 18SrRNA $18 \mathrm{~S}$ ribosomal RNA \\ 40sRNA 40S ribosomal protein S11 \\ acox1 peroxisomal acyl-coenzyme A oxidase 1 \\ actb $\quad \beta$-actin \\ ALA $\quad \alpha$-linolenic acid (18:3n-3) \\ ARA arachidonic acid (20:4n-6) \\ DGLA dihomo- $\gamma$-linoleic acid \\ DHA docosahexaenoic acid (22:6n-3) \\ ef-1a elongation factor 1-alpha \\ EFA essential fatty acids \\ elovl5 fatty acid elongase 5 \\ EPA eicosapentaenoic acid (20:5n-3) \\ FA fatty acid \\ FBW final body weight \\ fads6 fatty acid desaturase 6 \\ fas fatty acid synthase and \\ FCR feed conversion ratio \\ FM fish meal \\ FO fish oil \\ FRS Fisheries Research Station
}

gapdh glyceraldehyde 3-phosphate dehydrogenase

GLA $\quad \gamma$-linoleic acid (GLA)

HDL high-density lipoprotein cholesterol

HUFA highly unsaturated fatty acid

LA linoleic acid (18:2n-6)

LC-PUFA total long chain polyunsaturated fatty acid

LDL low-density lipoprotein cholesterol

MUFA monounsaturated fatty acid

n-3 PUFA total omega-3 polyunsaturated fatty acid

n-6 PUFA total omega- 6 polyunsaturated fatty acid

NLFA neutral lipid fatty acid

PER protein efficiency ratio

PLFA polar lipid fatty acids

ppara peroxisome proliferator-activated receptor $\alpha$

PUFA polyunsaturated fatty acids

rpl8 $\quad 60$ S ribosomal protein L8

SG specific growth rate

TAG triacylglycerol

TC total cholesterol

TG total growth

ZUT West Pomeranian University of Technology in Szczecin residues, as well as pathogens (Van der Spiegel et al., 2013). Currently studies assessing toxicological safety of new feed ingredients are conducted. For instance, Fedorova-Dahms et al. (2011) evaluated applicability of Schizochytrium sp. and revealed that DHA-rich alga is safe for intended use in human consumption and feed production. In contrast to marine fish, adverse effects, linked to feeds with lower EPA and DHA, on fish performance are rarer in freshwater aquaculture, such as Nile tilapia and common carp (Cyprinus carpio), because these fish have active metabolic pathways that convert dietary $\alpha$-linolenic acid (ALA) and linoleic acid (LA) to DHA, EPA and arachidonic acid (AA).

Common carp is one of the world's most consumed freshwater fish, cultured primarily in Europe and Asia. Globally, Cyprinids production accounts for around $40 \%$ but, in freshwater aquaculture, it is about $70 \%$ (Xu et al., 2014). Carp are reared predominantly in earthen ponds, and nutrition programmes are based on natural food supplemented with cereal grains, such as wheat, maize and barley, depending on price and local availability. The growing demand for aquaculture products, and the high phenotypic plasticity of carp, have led to intensive production models farmed in closed aquaculture systems. Such systems are based solely on artificial feed, often enriched with ingredients intended to improve the nutritional composition of products. Simply put, feeding carp with EFA-enriched feeds translate into increased FA concentrations in fillets (Csengeri et al., 2013). However, different concentrations and compositions of fat in feeds might affect fish blood biochemistry (cholesterol, triacylglycerol) (Nasir and Al-Sraji, 2013), liver histology (Poleksić et al., 2014), nutrient retention and, subsequently, compositions of their different tissues (Böhm et al., 2014) as well as gene expression in the biosynthesis of $n-3$ fatty acids (Ren et al., 2012). The effectiveness of FA profiling in fish might also depend on levels of lipid oxidation for internal requirements, such as energy production and storage, or membranes construction and maintenance (Sargent et al., 2002).

In the scientific literature, numerous studies report the effects of utilizing feeds containing different amounts of n-3 PUFAs on the chemical composition of fish. However, there is little information about the impact of FA from different sources (especially DHA and EPA) on the function of the organism, which - ultimately - shapes the chemical compositions and FA profiles of fillets. To determine these interactions, multidisciplinary studies are needed, considering molecular (gene activity analysis), biochemical (lipid profile in blood plasma), histological (hepatocyte morphology), and nutritional (chemical compositions and
FA profiles of fillets). Thus, the purpose of this study was to determine the influence of feeds containing different sources of fat (i.e. salmon oil, soybean and rapeseed oils and Schizochytrium sp. meal) on carp physiology by assessing: i) zootechnical parameters; ii) blood biochemistry (total cholesterol [TC], low-density lipoprotein cholesterol [LDL], highdensity lipoprotein cholesterol [HDL], triacylglycerol [TAG] and nonHDL cholesterol); iii) expression of five lipid metabolism-related genes in liver, i.e. peroxisome proliferator-activated receptor $\alpha$ (ppar $\alpha$ ), peroxisomal acyl-coenzyme A oxidase 1 (acox1), fatty acid desaturase 6 (fads6), fatty acid synthase (fas) and fatty acid elongase 5 (elovl5); iv) liver histomorphology; and v) total fat contents and fatty acid compositions in carp fillets.

\section{Materials and methods}

\subsection{Experimental diets}

Four isolipidic, isonitrogenous and isoenergetic diets, three experimental (CB1, CB2, CB3) and one control (CTRL) (Table 1), were designed to evaluate the impact of lipid sources on fish physiology and fillet composition. CB1, CB2 and CB3 were enriched with selenised yeast, microalgae (Spirulina sp., Chlorella sp. and Schizochytrium sp.) and macroalgae (Laminaria digitata) meals. Soybean and rapeseed oils (1:1) were the only lipid sources in the CTRL diet while, in CB3, salmon, soybean and rapeseed oils (1.05:1:1) were used. Lipid sources in CB1 and CB2 diets were rapeseed oil and Schizochytrium sp., which is ca. $66 \%$ fat (Allen et al., 2019). Diets were manufactured by SPAROS Lda (Olhão, Portugal). All powder ingredients were mixed, accordingly to the target formulations, in a double-helix mixer (500L, TGC Extrusion, Roullet-Saint-Estèphe, France) and ground (less than $200 \mu \mathrm{m}$ ) in a micropulveriser hammer mill (SH1, Hosokawa-Alpine, Germany). Diets (floating pellet size $6.0 \mathrm{~mm}$ ) were manufactured with a twin-screw extruder (BC45, Clextral, Firminy, France; screw diameter $55.5 \mathrm{~mm}$ ). Extrusion conditions were feeder rate $(77 \mathrm{~kg} / \mathrm{h})$, screw speed (247 rpm), water addition in barrel $1(330 \mathrm{ml} / \mathrm{min})$, temperature barrel $1\left(32-34{ }^{\circ} \mathrm{C}\right)$ and temperature barrel $3\left(111-115{ }^{\circ} \mathrm{C}\right)$. Extruded pellets were dried in a vibrating fluid bed dryer (DR100, TGC Extrusion, Roullet-Saint-Estèphe, France). Oils were added post-extrusion by vacuum coating (PG-10VCLAB, Dinnissen, Sevenum, Netherlands). After coating, diets were packed in bags and shipped to the West Pomeranian University of Technology in Szczecin (Poland, ZUT). 
Table 1

Formulation of experimental diets for common carp trail.

\begin{tabular}{|c|c|c|c|c|}
\hline Ingredients, \% & CTRL & CB1 & CB2 & CB3 \\
\hline Fishmeal $60^{\mathrm{a}}$ & 5.000 & 2.500 & 2.500 & 2.500 \\
\hline Porcine blood meal ${ }^{\mathrm{b}}$ & 2.000 & 2.000 & 2.000 & 2.000 \\
\hline Algae meal (Spirulina sp.) ${ }^{c}$ & & 1.000 & 1.000 & 1.000 \\
\hline Algae meal (Chlorella sp.) ${ }^{\mathrm{d}}$ & & 1.000 & 1.000 & 1.000 \\
\hline Algae meal (Schizochytrium sp.) ${ }^{\mathrm{e}}$ & & 3.125 & 1.563 & \\
\hline Soy protein concentrate ${ }^{\mathrm{f}}$ & 2.500 & 2.500 & 2.500 & 2.500 \\
\hline Corn gluten meal ${ }^{g}$ & 4.000 & 4.000 & 4.000 & 4.000 \\
\hline Soybean meal $44^{\mathrm{h}}$ & 25.000 & 25.000 & 25.000 & 25.000 \\
\hline Rapeseed meal ${ }^{\mathrm{i}}$ & 7.000 & 7.000 & 7.000 & 7.000 \\
\hline Sunflower meal $^{\mathrm{j}}$ & 12.500 & 12.500 & 12.500 & 12.500 \\
\hline Wheat meal ${ }^{\mathrm{k}}$ & 22.500 & 21.224 & 21.786 & 22.349 \\
\hline Wheat bran ${ }^{1}$ & 5.000 & 5.000 & 5.000 & 5.000 \\
\hline Corn meal ${ }^{\mathrm{m}}$ & 2.500 & 2.500 & 2.500 & 2.500 \\
\hline Salmon oil ${ }^{\mathrm{n}}$ & & & & 2.100 \\
\hline Soybean oil ${ }^{\circ}$ & 3.000 & & & 2.000 \\
\hline Rapeseed oil ${ }^{\circ}$ & 3.000 & 4.100 & 5.100 & 2.000 \\
\hline Vitamins and minerals premix ${ }^{p}$ & 1.000 & 1.000 & 1.000 & 1.000 \\
\hline Betaine $\mathrm{HCl}^{\mathrm{q}}$ & 0.100 & 0.100 & 0.100 & 0.100 \\
\hline Binders $^{r}$ & 1.000 & 1.000 & 1.000 & 1.000 \\
\hline Macroalgae meal (Laminaria digitata) ${ }^{\mathrm{s}}$ & & 0.541 & 0.541 & 0.541 \\
\hline Antioxidant ${ }^{\mathrm{t}}$ & 0.200 & 0.200 & 0.200 & 0.200 \\
\hline Sodium propionate ${ }^{\mathrm{u}}$ & 0.100 & 0.100 & 0.100 & 0.100 \\
\hline Sodium phosphate ${ }^{v}$ & 2.100 & 2.100 & 2.100 & 2.100 \\
\hline Selenised yeast ${ }^{\mathrm{w}}$ & & 0.010 & 0.010 & 0.010 \\
\hline L-Lysine ${ }^{x}$ & 0.700 & 0.700 & 0.700 & 0.700 \\
\hline L-Tryptophan ${ }^{y}$ & 0.200 & 0.200 & 0.200 & 0.200 \\
\hline DL-Methionine $^{z}$ & 0.600 & 0.600 & 0.600 & 0.600 \\
\hline \multicolumn{5}{|l|}{ Proximate composition (\%) } \\
\hline Crude protein & 30.20 & 30.60 & 30.40 & 30.30 \\
\hline Crude fat & 8.10 & 8.00 & 8.00 & 8.10 \\
\hline Crude ash & 3.00 & 3.00 & 3.00 & 3.00 \\
\hline Crude fiber & 5.00 & 5.00 & 5.00 & 5.00 \\
\hline \multicolumn{5}{|l|}{ Main fatty acids (\%) } \\
\hline $20: 5 n-3(E P A)$ & 0.05 & 0.27 & 0.22 & 0.05 \\
\hline $22: 6 n-3(D H A)$ & 0.09 & 0.62 & 0.38 & 0.12 \\
\hline$\Sigma \mathrm{EPA}+\mathrm{DHA}$ & 0.14 & 0.89 & 0.60 & 0.17 \\
\hline
\end{tabular}

${ }^{\text {a }}$ CONRESA 60: $61.2 \%$ crude protein (CP), 8.4\% crude fat (CF), Conserveros Reunidos S.A., Spain.

b Porcine blood meal: $89 \%$ CP, 1\% CF, SONAC BV, The Netherlands.

c Spirulina meal: $72 \% \mathrm{CP}, 1 \% \mathrm{CF}$, Willows Ingredients Ltd, Ireland.

d Chlorella meal: 62\% CP, 9\% CF, ALLMICROALGAE, Portugal.

e ALL-G RICH (Schizochytrium), Alltech Portugal.

f Soycomil P: $63 \% \mathrm{CP}, 0.8 \% \mathrm{CF}$, ADM, The Netherlands.

g Corn gluten meal: 61\% CP, 6\% CF, COPAM, Portugal.

h Solvent extracted soybean meal: $43.8 \% \mathrm{CP}, 3.3 \% \mathrm{CF}$, CARGILL, Spain.

i Defatted rapeseed meal: $32.7 \%$ CP, $4.1 \%$ CF, Ribeiro \& Sousa Lda, Portugal.

j Defatted sunflower meal: $29.1 \% \mathrm{CP}, 1.8 \% \mathrm{CF}$, Ribeiro \& Sousa Lda, Portugal.

k Wheat meal: $10.2 \%$ CP, $1.2 \%$ CF, Casa Lanchinha, Portugal.

${ }^{1}$ Wheat bran: $14.9 \%$ CP, $4.0 \%$ CF, Cerealis Moagens S.A., Portugal.

$\mathrm{m}$ Corn meal: $8 \% \mathrm{CP}, 3.7 \% \mathrm{CF}$, Ribeiro \& Sousa Lda, Portugal.

n Sopropêche, France.

- Lamotte Oils GmbH, Germany.

p INVIVONSA Portugal SA, Portugal: Vitamins (IU or $\mathrm{mg} / \mathrm{kg}$ diet): DL-alpha tocopherol acetate, $100 \mathrm{mg}$; sodium menadione bisulphate, $25 \mathrm{mg}$; retinyl acetate, $20000 \mathrm{IU}$; DL-cholecalciferol, $2000 \mathrm{IU}$; thiamin, $30 \mathrm{mg}$; riboflavin, $30 \mathrm{mg}$; pyridoxine, $20 \mathrm{mg}$; cyanocobalamin, $0.1 \mathrm{mg}$; nicotinic acid, $200 \mathrm{mg}$; folic acid, $15 \mathrm{mg}$; ascorbic acid, $500 \mathrm{mg}$; inositol, $500 \mathrm{mg}$; biotin, $3 \mathrm{mg}$; calcium panthotenate, $100 \mathrm{mg}$; choline chloride, $1000 \mathrm{mg}$, betaine, $500 \mathrm{mg}$. Minerals ( $\mathrm{g}$ or $\mathrm{mg} / \mathrm{kg}$ diet): copper sulphate, $9 \mathrm{mg}$; ferric sulphate, $6 \mathrm{mg}$; potassium iodide, $0.5 \mathrm{mg}$; manganese oxide, $9.6 \mathrm{mg}$; sodium selenite, $0.01 \mathrm{mg}$; zinc sulphate, $7.5 \mathrm{mg}$; sodium chloride, $400 \mathrm{mg}$; excipient wheat middling's.

q ORFFA, The Netherlands.

${ }^{r}$ CELATOM FP1SL (diatomite), Angelo Coimbra S.A., Portugal.

s Dry Laminaria digitata: $5.4 \% \mathrm{CP}, 0.5 \% \mathrm{CF}, 3700 \mathrm{mg}$ iodine $/ \mathrm{kg}$, Agrimer, France.

t VERDILOX, Kemin Europe NV, Belgium.

u PREMIX LDA., Portugal.

$\checkmark$ Vadequimica, Spain.

w ALKOSEL R397: 2200 mg selenium/kg, Lallemand, France.
${ }^{x}$ L-Lysine HCl 99\%: Ajinomoto Eurolysine SAS, France.

y TrypAMINO 98\%, Evonik Nutrition \& Care GmbH, Germany.

$\mathrm{z}$ DL-METHIONINE FOR AQUACULTURE 99\%, EVONIK Nutrition \& Care $\mathrm{GmbH}$, Germany.

\subsection{Feeding trial}

Ethical approval was obtained from the ethical committee of Faculty of Food Sciences and Fisheries (ZUT in Poland). We adhered to the "Guidelines for the treatment of animals in behavioural research and teaching" published in Animal Behaviour (Anon, 2012).

The fish trial was performed at the Fisheries Research Station (FRS), Nowe Czarnowo, Poland (N: 53 120 36" E: $14^{\circ} 27048^{\prime \prime}$ ), in floating cages (net volume $3 \mathrm{~m}^{3}$ each) submerged in cooling water discharged from the Dolna Odra Power Plant. One week prior to the start, 1200 carp (296 $\pm 10 \mathrm{~g}$ mean initial body weight) were selected from a pond farm located in Maliniec (NW Poland), transported to the FRS and randomly distributed $(\mathrm{n}=100)$ in 12 cages for acclimatization (100 fish/cage). The 100-day trial (July-October 2018) was performed in triplicate ( $\mathrm{n}=3 /$ diet). Feeding was by hand three times a day (at $10: 00,14: 00$ and 18:00 $\mathrm{h}$, in equal portions) until apparent satiation ( $2 \%$ metabolic dose). During the experiment, the temperature of water ranged between $13.3{ }^{\circ} \mathrm{C}$ and $34.2^{\circ} \mathrm{C}$.

\subsection{Measuring growth indices}

In order to evaluate the dietary impact on common carp, the following growth parameters were calculated: total growth (TG), feed conversion ratio (FCR), specific growth rate (SGR) and protein efficiency ratio (PER) using the following formulas:

$\mathrm{TG}=\frac{\text { weight gain }(\mathrm{g})}{\text { initial body weight }(\mathrm{g})} \times 100$

$\mathrm{FCR}=\frac{\text { feed consumed }(\mathrm{g})}{\text { weight gain }(\mathrm{g})}$

$\mathrm{SGR}=\left[\frac{(\mathrm{Ln} \text { final weight }- \text { Ln initial weight })}{\text { rearing days }}\right] \times 100$

$\mathrm{PER}=\frac{\text { weight gain }(\mathrm{g})}{\text { protein consumed }(\mathrm{g})}$

\subsection{Samples collection}

On three occasions (days 30, 60 and 100), five fish from each dietary treatment were anesthetised with $0.2 \mathrm{ml} / 1$ of 2 -phenoxyethanol (Sigma-Aldrich, St. Louis, USA) and blood drawn from the caudal vein using a sterile $5 \mathrm{ml}$ hypodermic syringe and a 23-gauge needle, transferred to $1.5 \mathrm{ml}$ tube (Eppendorf, Hamburg, Germany) before being stored overnight at $4{ }^{\circ} \mathrm{C}$ to clot. Then, fish were sacrificed using a lethal dose of the 2-phenoxyethanol ( $2 \mathrm{ml} / \mathrm{l}$ ). Liver samples ( $\mathrm{n}=5$ per treatment and sampling period) were collected immediately, preserved in DNA/RNA Shield ${ }^{\mathrm{TM}}$ (Zymo Research, Irvine, USA) and stored at $-80{ }^{\circ} \mathrm{C}$ until RNA extraction. Additionally, at the end of the feeding trial, liver samples (approx. $125 \mathrm{~mm}^{3}$ ) were collected for histomorphological assessment; these were placed in $5 \mathrm{ml}$ glass jars and covered with $10 \%$ buffered formalin solution for $5 \mathrm{~h}$ at room temperature.

\subsection{Plasma lipid profile}

After overnight clotting, blood samples were centrifuged (Centrifuge $5415 \mathrm{R}$, Eppendorf, Hamburg, Germany) at $4000 \times g$ for $10 \mathrm{~min}$. Plasma was transferred to labelled Eppendorf tubes and frozen $\left(-80^{\circ} \mathrm{C}\right)$ until analysis. Biochemical analyses of the lipid profile indices in plasma were conducted at SPSK- 2 hospital laboratory (Pomeranian 
Medical University, Szczecin, Poland). Total cholesterol (TC), lowdensity lipoprotein cholesterol (LDL), high-density lipoprotein cholesterol (HDL), triacylglycerol (TAG) and non-HDL cholesterol were assessed using dedicated reagent sets for chemiluminescence (CMIA) on an ARCHITECT c8000 clinical chemistry analyser (Abbott Diagnostics, Lake Forest, USA).

\subsection{Gene expression analysis}

At the Department of Aquatic Bioengineering and Aquaculture (ZUT in Szczecin), samples were homogenized in $750 \mu 1$ Tri Reagent ${ }^{\circledR}$ (Zymo Research, Irvine, USA) for $60 \mathrm{~s}$ with a Minilys ${ }^{\circledR}$ personal homogenizer (Bertin Corp., Rockville, USA). Total RNA was extracted using Direct$\mathrm{zol}^{\mathrm{TM}}$ RNA MiniPrep kit (Zymo Research, Irvine, USA), with $15 \mathrm{~min}$ DNase I treatment according to manufacturer instructions. Quantity and quality of RNA was assessed using NanoDrop 2000 (TermoFisher Scientific, Waltham, USA), all samples 260/280 ratio varied around 2.0. Reverse transcription was performed immediately after RNA extraction using a Reverse Transcription System kit (Promega, Walldorf, Germany) according to the manufacturer's instructions. Real-time PCR was performed on a QuantStudio ${ }^{\mathrm{TM}} 3$ (TermoFisher Scientific, Waltham, USA) using PowerUp ${ }^{\mathrm{TM}}$ SYBR $^{\mathrm{TM}}$ Green Master Mix 2x (TermoFisher Scientific, USA), $0.3 \mu \mathrm{M}$ of each primer and $1 \mu \mathrm{l}$ of cDNA templates in a final volume of $10 \mu \mathrm{l}$. The reaction was conducted using $2 \mathrm{~min}$ of activation at $50{ }^{\circ} \mathrm{C}, 2 \mathrm{~min}$ at $95{ }^{\circ} \mathrm{C}, 40$ cycles of denaturation at $95{ }^{\circ} \mathrm{C}$ for $1 \mathrm{~s}$ and annealing/extending at $60{ }^{\circ} \mathrm{C}$ for $30 \mathrm{~s}$. Melting curve analysis $\left(60-95{ }^{\circ} \mathrm{C}\right.$ ) was conducted at the end of each PCR thermal profile and negative samples for each primers set were run to ensure the specificity of amplification. The stability of six reference genes [i.e. $18 \mathrm{~S}$ ribosomal RNA (18SrRNA), 40S ribosomal protein S11 (40sRNA), 60S ribosomal protein L8 ( $r p l 8$ ), $\beta$-actin ( $a c t b)$, glyceraldehyde 3-phosphate dehydrogenase (gapdh) and elongation factor 1-alpha (ef-1a)] was evaluated using geNorm and NormFinder algorithms (Table 2). Activities of five lipid metabolism-related genes [i.e. peroxisome proliferator-activated receptor $\alpha$ (ppar $\alpha$ ), peroxisomal acyl-coenzyme A oxidase 1 (acox1), fatty acid desaturase 6 (fads6), fatty acid synthase (fas) and fatty acid elongase 5 (elovl5)] against two reference genes (40sRNA and rpl8) were assessed. Relative gene expression was calculated using GeneEx (MultiD Analyzes, Sweden) software and the results normalised against expression in livers sampled at the beginning of the trial.

\subsection{Liver histomorphology}

Livers fragments were fixed in buffered formalin and samples dehydrated through alcohol and saturated in intermediate solutions (benzene, benzene: paraffin) before being embedded in paraffin blocks, trimmed, sectioned ( $4 \pm 1 \mu \mathrm{m}$, Rotary Microtome MPS-2, Opta-Tech, Poland), stained with haematoxylin and eosin, and mounted on slides with DPX balsam (Burck, 1975). Twelve glass slides (3 fish $\times 4$ slides) for each diet were randomly selected and examined by two members of the laboratory using an Eclipse E600 microscope (Nikon, Nikon, Japan) with 100x objective and, using NIS-Elements Basic Research software (Nikon Instruments Europe B.V, Japan), screened for hepatocyte (C) and hepatocyte nucleus $(\mathrm{N})$ areas (300 measurements/parameter). Additionally, the nuclear:cytoplasm areas ratio (N/C) of hepatocytes were calculated, and the significance of observed differences was assessed for each parameter.

\subsection{Fillets fatty acid composition}

Samples of muscle tissue from five fish per diet were prepared as pooled homogenates ( $n=5$ per treatment) and all following analyses were run in triplicates. Crude lipid content was determined gravimetrically after Soxhlet lipid extraction using a Tecator Soxtec System HT

Table 2

Sequences of qPCR primers for the detection of reference and lipid metabolism related genes in common carp by real-time PCR.

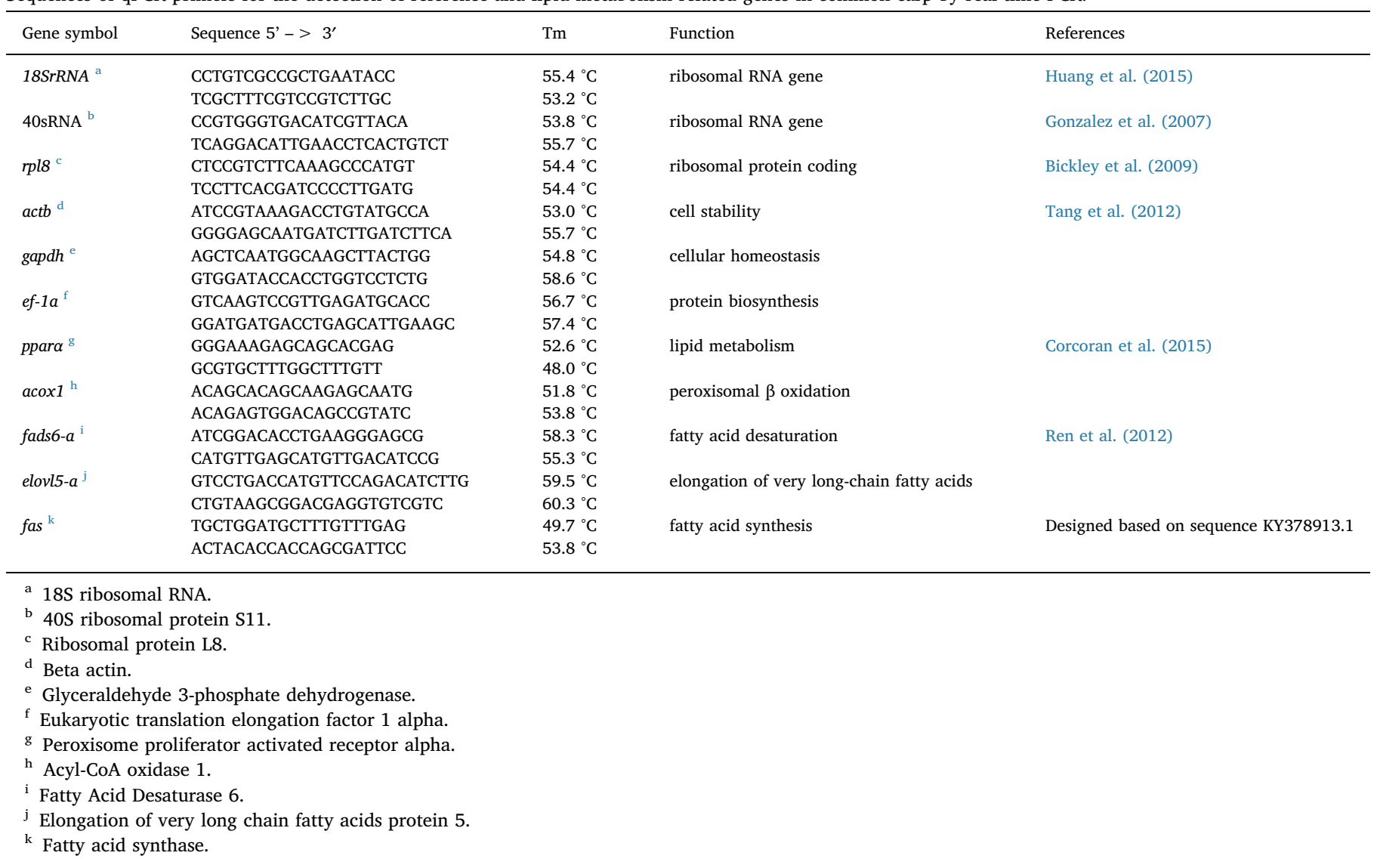


1043 (FOSS Analytical Co., Ltd., Hillerød, Denmark). Fatty acid profile was assessed by Polcargo (Szczecin), using gas chromatography in accordance with PN-EN ISO 12966-1:2015-01. Based on the profiles obtained, specific indicators, such as total saturated fatty acid (SFA), total monounsaturated fatty acid (MUFA), total polyunsaturated fatty acid (PUFA), total long chain polyunsaturated fatty acid (LC-PUFA), total omega-3 polyunsaturated fatty acid (n-3 PUFA), total omega- 6 polyunsaturated fatty acid (n-6 PUFA) and ratio between n- 3 and n- 6 , were calculated.

\subsection{Statistical analysis}

All data are shown as mean \pm standard deviation unless otherwise specified. All statistical analyses were performed using Statistica 13 (StatSoft, Inc., Krakow, Poland). Normal distribution of data was assessed with Shapiro-Wilk test (Significance level p $<0.05$ ). Differences between parameters were determined using the KruskalWallis test followed by Tukey HSD post-hoc test. Additionally, two-way ANOVA test was applied to assess influence of blends on blood biochemistry parameters. Differences were considered statistically significant at $\mathrm{p} \leq 0.05$.

\section{Results}

\subsection{Growth indices}

At the beginning of experiment no significant differences were found for initial body weight. At the end of the 100-day feeding trial period, there were significant differences in weights between CTRL and CB1-3 treatments (Table 3), i.e. later groups had significantly higher final body weight (FBW). No differences were found in growth response (TG or SGR) and feed utilization indices (FCR or PER), and no differences in mortality or disease were noted within or between groups.

\subsection{Blood biochemistry}

Two-way ANOVA showed that total and non-HDL cholesterol were affected by diet, sampling time, and there was an interaction between these factors (Table 4). HDL was not affected by any factor, while LDL was affected strongly by sampling time. TAG concentrations were time and interaction between time and diet dependent. Non-HDL concentrations associated with CB1-3 were significantly different ( $p \leq 0.05$ ) from CTRL at the end of trial, but not one another. However, CB1-2 TC was significantly different $(p \leq 0.05)$ from CRTL after 60 days and remained so at 100 days. All parameters in plasma from carp fed CB1-3 increased during the trial; the opposite was observed in CTRL fish for TC, HDL, LDL and non-HDL, but TAG increased. The increase in TAG was less in fish receiving the experimental diets (CB1-3, increase
41-72\%) compared with CTRL fish (183\%, $\mathrm{p} \leq 0.05)$. In fish receiving CB3, changes in TC and non-HDL were the greatest, while TAG, HDL and LDL were the lowest overall throughout the experiment.

\subsection{Gene expression}

Among six reference genes examined, expressions of rpl8 and 40sRNA were the lowest and most stable across all samples and dietary treatments. Therefore, both genes were used as internal controls subsequently (Fig. 1). The expression of genes related to lipid metabolism pathways in the liver of common carp are shown in Fig. 2. Dietary levels of EPA and DHA affected significantly the expression of fads6, fas, elovl5- $a$, ppara and acox 1 during the 100-day feeding trial. Liver expression of fas, elovl5- $a$ and ppara increased significantly in carp fed diets containing more EPA and DHA (i.e. CB1, CB2) with an opposite (i.e. down-regulation with increasing EPA and DHA) observed for acox1. Transcripts of fads6- $a$ in the liver of carp fed diets containing more EPA and DHA were stable, while decreased in CTRL and CB3-fed fish.

\subsection{Liver histomorphology}

No pathological (disease-related) indicators were found in any samples. However, there were significant differences $(\mathrm{p} \leq 0.05)$ in hepatocyte morphologies amongst the treatments (Table 5). More specifically, fish fed CB1 had the smallest hepatocytes and nuclei, while the largest were noticed in livers from fish fed CB2. N/C ratios were largest for CB2 (0.204 \pm 0.004) and smallest for CB3 (0.164 \pm 0.004$)$.

\subsection{Fatty acid profile}

Significant differences ( $\mathrm{p} \leq 0.05$ ) in total lipid content of fillets were found amongst the dietary treatments (Table 6). Total n-3 PUFA, total n-3 LC PUFA, total PUFA, ALA and EPA plus DHA were significantly different in fillets from fish fed CB1-3 ( $\mathrm{p} \leq 0.05)$ compared with CTRL fillets. The highest ( $\mathrm{p} \leq 0.05$ ) concentrations of EPA and DHA, n-3/n-6 ratio $(0.38 \pm 0.01)$ were in fillets from fish fed CB1. Simultaneously, significantly ( $\mathrm{p} \leq 0.05$ ) lower concentrations of palmitic acid (C16:0), total MUFA, oleic acid (C18:1n9c), $\gamma$-linoleic acid (GLA), dihomo- $\gamma$-linoleic acid (DGLA) and arachidonic acid (ARA) were noted in fillets from all experimental groups (i.e. fish fed CB1-3).

\section{Discussion}

Demand for essential omega-3 long chain polyunsaturated fatty acids has led to utilization of various plant and animal ingredients in aquafeed production (Tocher et al., 2019). In the present study, we demonstrated a range of impacts on common carp physiology

Table 3

Growth and feed utilization indices of common carp fed diet containing different sources of fat.

\begin{tabular}{|c|c|c|c|c|}
\hline & CTRL & CB1 & $\mathrm{CB} 2$ & CB3 \\
\hline $\mathrm{IBW}^{\mathrm{a}}(\mathrm{g})$ & $300.67 \pm 29.01$ & $294.67 \pm 15.37$ & $294.67 \pm 14.57$ & $291.67 \pm 20.26$ \\
\hline FBW $^{\mathrm{b}}(\mathrm{g})$ & $1085.22 \pm 16.42^{\mathrm{a}}$ & $1192.64 \pm 75.59^{b}$ & $1188.73 \pm 49.94^{b}$ & $1217.55 \pm 36.18^{b}$ \\
\hline $\mathrm{TG}^{\mathrm{c}}(\%)$ & $263.14 \pm 35.05$ & $305.81 \pm 38.40$ & $303.63 \pm 12.09$ & $319.28 \pm 40.11$ \\
\hline $\mathrm{FCR}^{\mathrm{d}}$ & $1.52 \pm 0.12$ & $1.45 \pm 0.11$ & $1.45 \pm 0.09$ & $1.39 \pm 0.11$ \\
\hline $\operatorname{SGR}^{\mathrm{e}}(\% / \mathrm{d})$ & $1.29 \pm 0.10$ & $1.40 \pm 0.10$ & $1.40 \pm 0.03$ & $1.43 \pm 0.10$ \\
\hline $\operatorname{PER}^{\mathrm{f}}(\mathrm{g} / \mathrm{g})$ & $2.18 \pm 0.06$ & $2.29 \pm 0.06$ & $2.28 \pm 0.14$ & $2.38 \pm 0.03$ \\
\hline
\end{tabular}

Explanations: Results represent mean \pm standard deviation $(n=3)$. Values with different superscripts in rows indicate significant differences ( $\mathrm{p} \leq 0.05)$.

a Initial body weight.

b Final body weight.

c Total growth.

d Feed conversion ratio.

e Specific growth rate.

${ }^{\mathrm{f}}$ Protein efficiency ratio. 
Table 4

Dietary influence on blood biochemical parameters of common carp.

\begin{tabular}{|c|c|c|c|c|c|c|}
\hline & & Total cholesterol (mg/dl) & Cholesterol HDL (mg/dl) & Cholesterol LDL (mg/dl) & Triacylglycerol (mg/dl) & Cholesterol non-HDL (mg/dl) \\
\hline \multirow[t]{3}{*}{ CTRL } & $30 \mathrm{~d}$ & $144.75 \pm 5.85^{\mathrm{A} \mathrm{a}}$ & $7.40 \pm 1.34^{\mathrm{A} \mathrm{a}}$ & $8.60 \pm 1.52^{\mathrm{A} \mathrm{a}}$ & $262.60 \pm 39.90^{\mathrm{A} \mathrm{a}}$ & $142.40 \pm 12.74^{\mathrm{A} \mathrm{a}}$ \\
\hline & $60 \mathrm{~d}$ & $137.67 \pm 9.87^{\mathrm{A} a}$ & $6.75 \pm 0.96^{\mathrm{A} \mathrm{a}}$ & $6.20 \pm 2.95^{\mathrm{A} \mathrm{ab}}$ & $379.25 \pm 30.58^{\mathrm{Ab}}$ & $126.40 \pm 9.40^{\mathrm{A} a}$ \\
\hline & $100 \mathrm{~d}$ & $135.67 \pm 27.54^{\mathrm{A} \mathrm{a}}$ & $5.75 \pm 1.26^{\mathrm{A} \mathrm{a}}$ & $6.00 \pm 1.00^{\mathrm{A} \mathrm{b}}$ & $444.75 \pm 27.24^{\mathrm{Ac}}$ & $114.50 \pm 19.09^{\mathrm{A} \mathrm{a}}$ \\
\hline \multirow[t]{3}{*}{$\mathrm{CB} 1$} & $30 \mathrm{~d}$ & $173.80 \pm 26.99^{\mathrm{A} \mathrm{a}}$ & $6.50 \pm 1.29^{\mathrm{A} \mathrm{a}}$ & $9.67 \pm 2.52^{\mathrm{A} \mathrm{a}}$ & $239.80 \pm 29.10^{\mathrm{A} \mathrm{a}}$ & $167.00 \pm 26.63^{\mathrm{Aa}}$ \\
\hline & $60 \mathrm{~d}$ & $189.00 \pm 1.41^{\mathrm{B} \mathrm{a}}$ & $6.50 \pm 0.71^{\mathrm{Aa}}$ & $10.00 \pm 1.41^{\mathrm{A} \mathrm{a}}$ & $398.00 \pm 45.25^{\mathrm{Ab}}$ & $183.00 \pm 1.41^{\mathrm{B} \mathrm{a}}$ \\
\hline & $100 \mathrm{~d}$ & $212.20 \pm 28.33^{\mathrm{B} \mathrm{a}}$ & $7.20 \pm 2.17^{\mathrm{A} \mathrm{a}}$ & $15.80 \pm 7.26^{\mathrm{B} \mathrm{a}}$ & $412.60 \pm 76.81^{\mathrm{Ab}}$ & $205.00 \pm 27.47^{\mathrm{B} \mathrm{a}}$ \\
\hline \multirow[t]{3}{*}{ CB2 } & $30 \mathrm{~d}$ & $157.60 \pm 13.43^{\mathrm{Aa}}$ & $6.67 \pm 2.08^{\mathrm{A} \mathrm{a}}$ & $9.75 \pm 1.71^{\mathrm{A} \mathrm{a}}$ & $218.50 \pm 47.85^{\mathrm{Aa}}$ & $149.40 \pm 14.45^{\mathrm{A} \mathrm{a}}$ \\
\hline & $60 \mathrm{~d}$ & $171.33 \pm 19.55^{\mathrm{B}} \mathrm{ab}$ & $7.67 \pm 0.58^{\mathrm{A} \mathrm{a}}$ & $10.33 \pm 2.08^{\mathrm{A} \mathrm{a}}$ & $358.00 \pm 82.31^{\mathrm{Ab}}$ & $163.67 \pm 19.14^{\mathrm{AB} a b}$ \\
\hline & $100 \mathrm{~d}$ & $201.60 \pm 21.81^{\mathrm{B} \mathrm{b}}$ & $7.80 \pm 1.79^{\mathrm{A} \mathrm{a}}$ & $17.60 \pm 5.94^{\mathrm{B} \mathrm{a}}$ & $369.33 \pm 53.61^{\mathrm{A} \mathrm{b}}$ & $193.80 \pm 21.72^{\mathrm{B} \mathrm{b}}$ \\
\hline \multirow[t]{3}{*}{ CB3 } & $30 \mathrm{~d}$ & $141.67 \pm 26.71^{\mathrm{A} \mathrm{a}}$ & $7.33 \pm 0.58^{\mathrm{A} \mathrm{a}}$ & $9.00 \pm 2.07^{\mathrm{A} \mathrm{a}}$ & $252.60 \pm 37.69^{\mathrm{A} \mathrm{a}}$ & $134.33 \pm 16.65^{\mathrm{Aa}}$ \\
\hline & $60 \mathrm{~d}$ & $157.00 \pm 7.07^{\mathrm{AB} \mathrm{ab}}$ & $7.50 \pm 1.91^{\mathrm{A} \mathrm{a}}$ & $9.40 \pm 5.03^{\mathrm{A} \mathrm{a}}$ & $330.50 \pm 62.34^{\text {Aab }}$ & $141.00 \pm 18.03^{\mathrm{A} \mathrm{ab}}$ \\
\hline & $100 \mathrm{~d}$ & $194.60 \pm 28.26^{\mathrm{AB} \mathrm{b}}$ & $7.80 \pm 1.30^{\mathrm{A} \mathrm{a}}$ & $17.40 \pm 6.35^{\mathrm{B} \mathrm{a}}$ & $357.00 \pm 60.32^{\mathrm{Ab}}$ & $187.00 \pm 28.38^{\mathrm{B} b}$ \\
\hline \multirow[t]{3}{*}{ Significance } & Diet & $* *$ & n.s. & n.s. & n.s. & $* *$ \\
\hline & Time & $* *$ & n.s. & $* *$ & $* *$ & $* *$ \\
\hline & DxT & $* *$ & n.s. & n.s. & $*$ & $* *$ \\
\hline
\end{tabular}

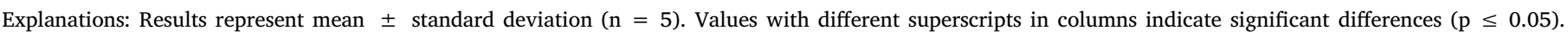

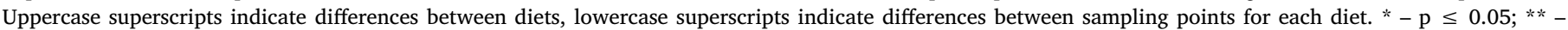
$\mathrm{p} \leq 0.01$; n.s. - differences not significant; $\mathrm{D}$ - diet; $\mathrm{T}$ - time (sampling point).

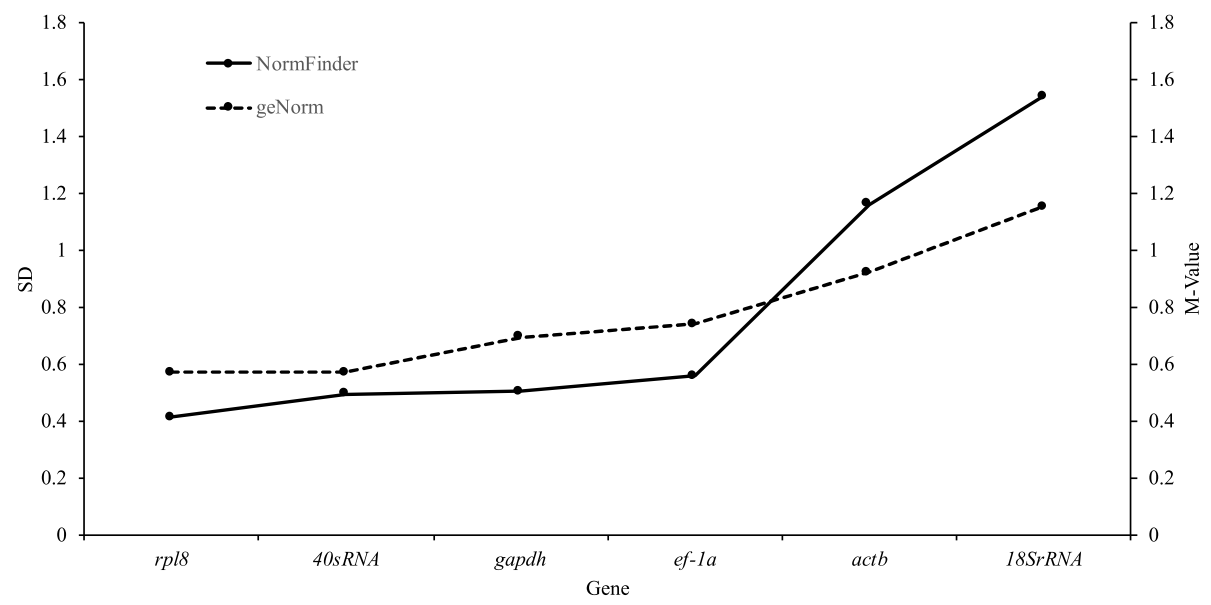

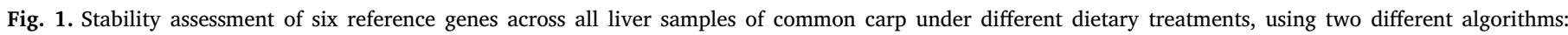
NormFinder (SD) and geNorm (M-Value) provided in GeneEx software.

associated with feed blends containing various sustainable sources of fat. Zootechnical parameters revealed that carp fed CB1-3 were heavier (FBW) compared with CTRL fish. This difference in FBW was presumably the result of including DHA-enrich algae and salmon oil in test diets, as formulated diets were isoenergetic. Comparable results have been found for rainbow trout (Oncorhynchus mykiss), salmon (Salmo salar) and whiteleg shrimp (Litopenaeus vannamei), the growth of which were higher when fed DHA-rich diets (Bell et al., 2001, 2003, Araújo et al., 2019). However, the differences in FBW for CB1-3 might also arise from addition of selenized yeast in the blends, since organic selenium is more bioavailable than the inorganic form and might affect positively fish health and performance (Berntssen et al., 2018).

Biochemical parameters revealed significantly higher TC concentrations in plasma from fish fed CB1 (containing 3.125\% Schizochytrium sp.), which contained the most EPA and DHA. Our results are consistent with those obtained for European seabass (Dicentrarchus labrax); TC was elevated in fish fed more FAs (Richard et al., 2006a). Some studies have suggested there were no effects of EPA/DHA on Atlantic salmon TC (Jin et al., 2017) whilst others demonstrated TC decreased in blunt snout bream (Megalobrama amblycephala, Lu et al., 2013) and rainbow trout (Richard et al., 2006b) fed diets with higher concentrations of n-3 LC-PUFA. In our study, high plasma TC could have influenced CB1-3 FBW. In some fish species, such as rainbow trout and Japanese flounder (Paralichthys olivaceus), higher TC improved significantly feed intakes and weight gain (Twibell and
Wilson, 2004; Deng et al., 2010). However, in most aquaculture species, TC depends on feed compositions including the source of dietary protein (Romarheim et al., 2006). In most cases, increased TC (likewise TAG) reflects increased internal lipid transport (Du et al., 2005). During the experiment, we also observed increased HDL, LDL and non-HDL in fish receiving CB1-3 as well as a decrease in these indices in the CTRL fish. Deng et al. (2010) observed changes in blood lipoprotein concentrations (HDL, LDL, VLDL, IDL, intermediate density lipoproteins), revealing that fish protein-based diets increased lipoprotein, while plant protein-based diets decreased them. These responses and interactions are specific to species, dietary treatments, and sex (Deng et al., 2010). For carp in particular, this is the first report demonstrating that non-HDL concentrations depend on feed compositions. Therefore, further studies are needed to identify the sources of variation and the optimal diet for fillet composition.

Blood TAG concentrations showed no significant differences amongst dietary treatments, which might be attributed to the isolipidic $(8 \%)$ feed blends. TAG in blood or liver is a derivative of fat in feeds ( $\mathrm{Lu}$ et al., 2013). Feeding blunt snout bream with control (5\% fat) and highfat (15\% fat) diets showed that hepatic TAG was higher in fish fed the high-fat diet. In contrast, plasma TAG was higher in the control group (5\%), suggesting lipid transport from the liver is impacted by high-fat diets (Lu et al., 2013). TAG metabolism also depends on qualitative fat composition in the feed. Results from nutritional trials showed positive (Lemaire et al., 1991; Kjær et al., 2008) and negative (Jordal et al., 
A

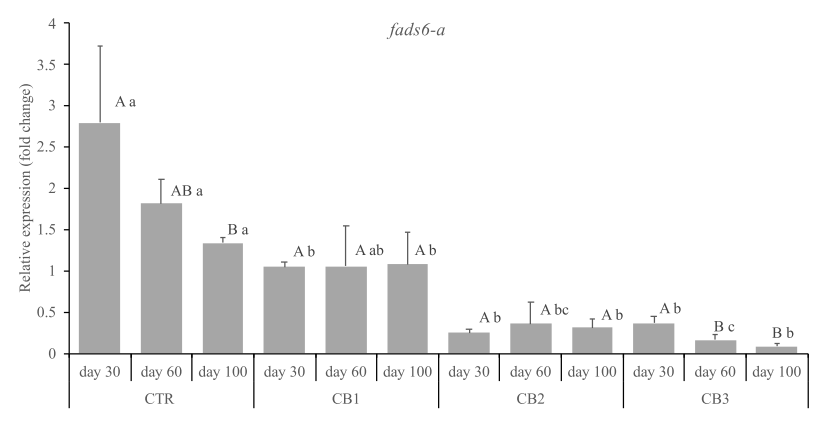

C

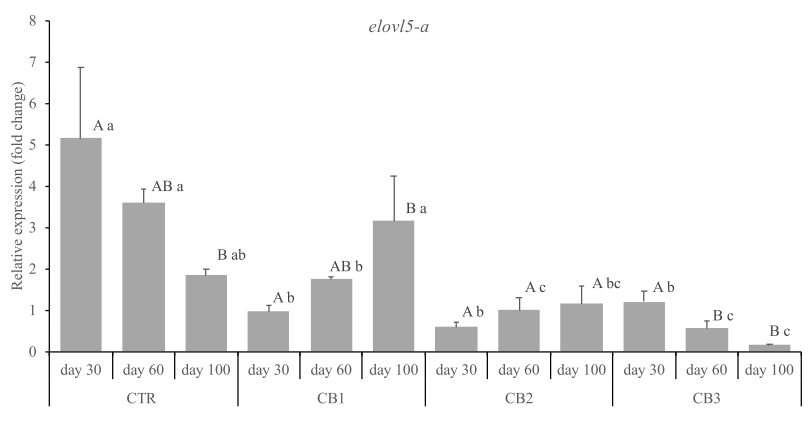

B

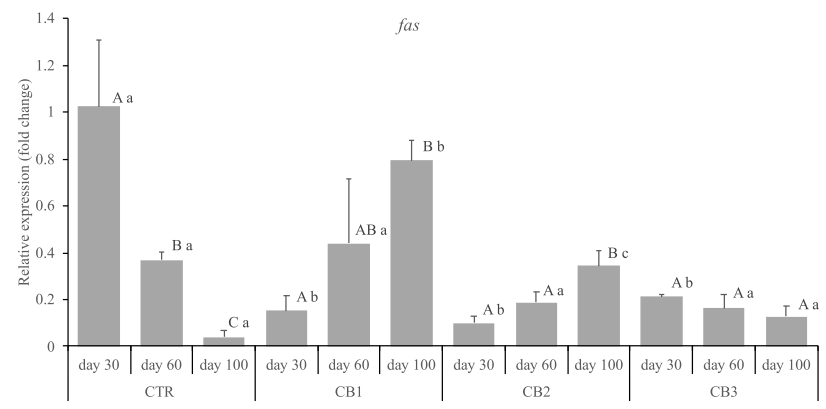

$\mathrm{D}$

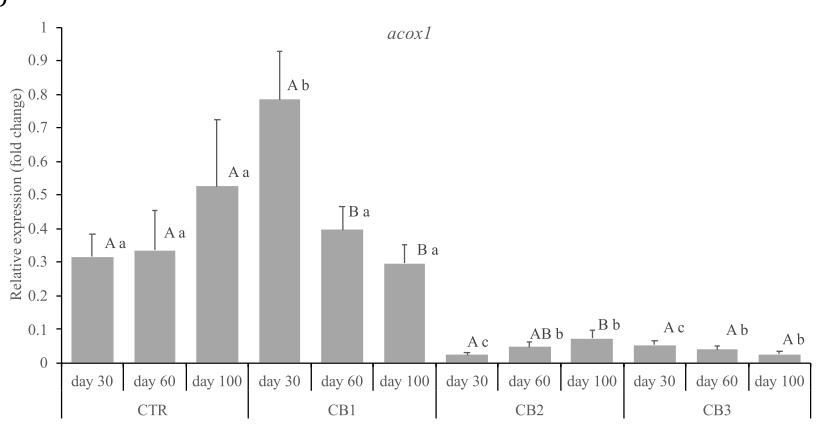

$\mathrm{E}$

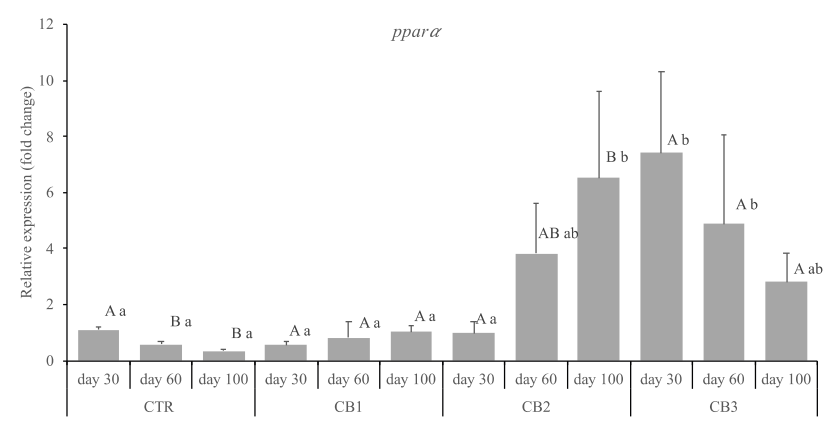

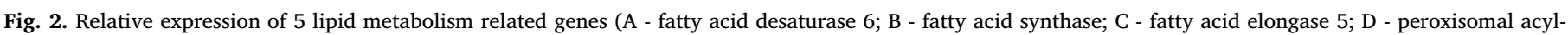

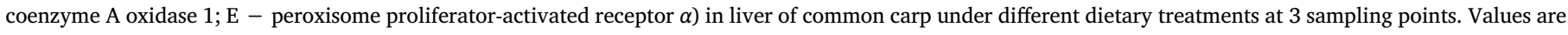

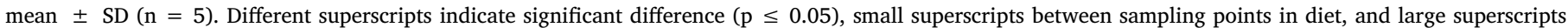
between different diets at each sampling point.

2007; Leaver et al., 2008) correlations between increased n-3 PUFA feed content and reduced plasma TAG in European seabass and Atlantic salmon. In our study, plasma TAG was similar across all dietary treatments at all time points, despite differences in feed compositions. Similar results were observed in Atlantic salmon fed with a diet where FO was replaced by plant oils with the same fish meal (FM) contents
(Jordal et al., 2007). During our trial, plasma TAG increased, probably in relation to increased secretion of TAG-rich VLDL (very low-density lipoprotein) particles from the liver in the post-absorptive phase, which is regulated by dietary FA availability and composition (Torstensen et al., 2011). The greatest increase (183\%) was in CTRL fish, which received the diet with the most plant ingredients. Torstensen et al.

Table 5

Liver histological parameters of common carp fed with different sources of fat.

\begin{tabular}{lllll}
\hline & CTRL & CB1 & CB2 \\
\hline Hepatocyte area $\left(\mu \mathrm{m}^{2}\right)$ & $123.37 \pm 7.10^{\mathrm{ab}}$ & $93.19 \pm 30.21^{\mathrm{a}}$ & $154.82 \pm 13.02^{\mathrm{b}}$ \\
Hepatocyte nucleus area $\left(\mu \mathrm{m}^{2}\right)$ & $20.68 \pm 1.28^{\mathrm{a}}$ & $17.08 \pm 4.73^{\mathrm{a}}$ & $31.00 \pm 2.43^{\mathrm{b}}$ & $120.26 \pm 8.27^{\mathrm{ab}}$ \\
$\mathrm{N} / \mathrm{C}^{1}$ & $0.175 \pm 0.007^{\mathrm{a}}$ & $0.197 \pm 0.013^{\mathrm{b}}$ & $0.204 \pm 0.004^{\mathrm{b}}$ & $18.81 \pm 1.53^{\mathrm{a}}$
\end{tabular}

Explanations: Results represent mean \pm standard deviation $(\mathrm{n}=3)$. Values with different superscripts in rows indicate significant differences $(\mathrm{p} \leq 0.05) .{ }^{1}$ Hepatocyte nucleus area/hepatocyte area. 
Table 6

Muscle fatty acid composition (\% of total fatty acids) of common carp fed blends with different sources of fat.

\begin{tabular}{|c|c|c|c|c|}
\hline & CTRL & CB1 & CB2 & CB3 \\
\hline Crude fat (\%) & $2.98 \pm 0.36^{\mathrm{a}}$ & $3.68 \pm 0.52^{\mathrm{ab}}$ & $3.07 \pm 0.13^{\mathrm{a}}$ & $4.51 \pm 0.16^{\mathrm{b}}$ \\
\hline $\mathrm{C} 16: 0$ (PA) & $16.19 \pm 0.07^{d}$ & $14.90 \pm 0.03^{\mathrm{b}}$ & $14.82 \pm 0.06^{\mathrm{a}}$ & $15.23 \pm 0.08^{c}$ \\
\hline C18:0 (SA) & $3.70 \pm 0.01^{\mathrm{b}}$ & $3.45 \pm 0.03^{\mathrm{a}}$ & $3.67 \pm 0.04^{\mathrm{b}}$ & $3.70 \pm 0.01^{\mathrm{b}}$ \\
\hline Total SFA ${ }^{a}$ & $24.55 \pm 1.79$ & $24.34 \pm 2.14$ & $24.22 \pm 2.08$ & $24.07 \pm 1.97$ \\
\hline $\mathrm{C} 18: 1 \mathrm{n} 9 \mathrm{c}(\mathrm{OA})$ & $43.58 \pm 0.02^{\mathrm{d}}$ & $40.31 \pm 0.23^{\mathrm{b}}$ & $38.96 \pm 0.86^{\mathrm{a}}$ & $42.95 \pm 0.07^{c}$ \\
\hline Total MUFA & $53.95 \pm 0.02^{\mathrm{c}}$ & $51.98 \pm 0.21^{\mathrm{b}}$ & $50.17 \pm 0.84^{\mathrm{a}}$ & $52.68 \pm 0.05^{\mathrm{b}}$ \\
\hline C18:3n3 (ALA) & $1.55 \pm 0.02^{\mathrm{a}}$ & $2.18 \pm 0.01^{\mathrm{c}}$ & $2.05 \pm 0.02^{\mathrm{b}}$ & $2.08 \pm 0.01^{\mathrm{b}}$ \\
\hline $\mathrm{C} 20: 5 \mathrm{n} 3$ (EPA) & $0.17 \pm 0.01^{\mathrm{a}}$ & $0.84 \pm 0.01^{\mathrm{c}}$ & $0.81 \pm 0.03^{\mathrm{c}}$ & $0.50 \pm 0.00^{\mathrm{b}}$ \\
\hline C22:6n3 (DHA) & $0.91 \pm 0.02^{\mathrm{a}}$ & $3.33 \pm 0.07^{\mathrm{d}}$ & $2.97 \pm 0.19^{c}$ & $1.80 \pm 0.03^{\mathrm{b}}$ \\
\hline Total n-3 PUFA ${ }^{c}$ & $2.68 \pm 0.02^{\mathrm{a}}$ & $6.48 \pm 0.07^{\mathrm{d}}$ & $5.96 \pm 0.24^{\mathrm{c}}$ & $4.49 \pm 0.03^{\mathrm{b}}$ \\
\hline Total n-3 LC PUFA ${ }^{d}$ & $1.12 \pm 0.01^{\mathrm{a}}$ & $4.27 \pm 0.07^{\mathrm{d}}$ & $3.88 \pm 0.21^{\mathrm{c}}$ & $2.38 \pm 0.03^{\mathrm{b}}$ \\
\hline C18:2n6c (LA) & $15.47 \pm 0.04^{\mathrm{a}}$ & $15.26 \pm 0.09^{\mathrm{a}}$ & $16.97 \pm 0.22^{\mathrm{c}}$ & $16.49 \pm 0.03^{\mathrm{b}}$ \\
\hline C18:3n6 (GLA) & $0.69 \pm 0.00^{\mathrm{d}}$ & $0.31 \pm 0.01^{\mathrm{a}}$ & $0.39 \pm 0.01^{b}$ & $0.48 \pm 0.00^{c}$ \\
\hline C20:3n6 (DGLA) & $0.73 \pm 0.00^{c}$ & $0.54 \pm 0.03^{\mathrm{a}}$ & $0.66 \pm 0.04^{\mathrm{b}}$ & $0.62 \pm 0.01^{\mathrm{b}}$ \\
\hline $\mathrm{C} 20: 4 \mathrm{n} 6(\mathrm{AA})$ & $1.56 \pm 0.02^{\mathrm{c}}$ & $0.81 \pm 0.03^{\mathrm{a}}$ & $1.08 \pm 0.10^{\mathrm{b}}$ & $0.98 \pm 0.01^{\mathrm{b}}$ \\
\hline Total n-6 PUFA ${ }^{e}$ & $18.45 \pm 0.03^{\mathrm{b}}$ & $16.90 \pm 0.14^{\mathrm{a}}$ & $19.10 \pm 0.36^{\mathrm{c}}$ & $18.57 \pm 0.02^{\mathrm{b}}$ \\
\hline Total PUFA ${ }^{f}$ & $22.10 \pm 0.04^{\mathrm{a}}$ & $24.09 \pm 0.22^{\mathrm{b}}$ & $25.90 \pm 0.63^{\mathrm{c}}$ & $23.81 \pm 0.01^{\mathrm{b}}$ \\
\hline $\mathrm{EPA}+\mathrm{DHA}$ & $1.08 \pm 0.02^{\mathrm{a}}$ & $4.17 \pm 0.07^{\mathrm{d}}$ & $3.78 \pm 0.22^{\mathrm{c}}$ & $2.30 \pm 0.03^{\mathrm{b}}$ \\
\hline$n-3 / n-6$ & $0.15 \pm 0.01^{\mathrm{a}}$ & $0.38 \pm 0.01^{\mathrm{d}}$ & $0.31 \pm 0.01^{c}$ & $0.24 \pm 0.01^{\mathrm{b}}$ \\
\hline
\end{tabular}

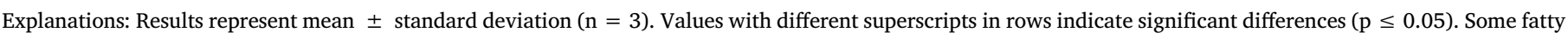

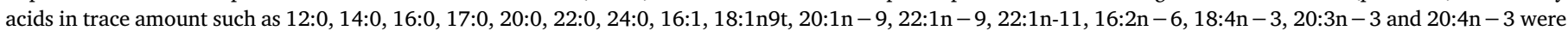
not listed.

a Saturated fatty acids.

b Monounsaturated fatty acids.

c Omega-3 polyunsaturated fatty acids.

d Omega-3 long-chain $\left(\mathrm{C}_{20-24}\right)$ polyunsaturated fatty acids.

e Omega-6 polyunsaturated fatty acids.

f Polyunsaturated fatty acids.

(2011) found significantly and consistently increased plasma TAG in fish fed a diet containing high-plant protein and vegetable oils, demonstrating an interaction between dietary lipids and proteins with lipid metabolic consequences. Increased TAG concentrations were also associated with lower water temperatures (Torstensen et al., 2011), in line with the decrease observed in our study $\left(28.9{ }^{\circ} \mathrm{C}\right.$ - 23rd July to $14.6{ }^{\circ} \mathrm{C}$ - 30th October). Data for the effects of dietary fat intakes and quality on serum indices were inconclusive, meaning further studies are required to better understand the regulation of indices related to lipid metabolism in common carp.

As a freshwater aquaculture species, carp can synthesise HUFA, and nutritional trials with Cyprinus carpio var. Jian showed the efficiency of HUFA biosynthesis depended mainly on the quality and quantity of FAs in feeds (Ren et al., 2012). Ren et al. (2012) also demonstrated greater expression of genes involved in HUFA biosynthesis, specifically fads6- $a$ and elovl5- $a$, when the fish were fed LA and ALA-fortified diets compared to EPA/DHA rich diet. In our experiment, fads6-a expression in fish fed CB1 and CB2 (highest EPA/DHA concentrations) did not differ, which confirms a mechanism inhibiting fads6- $a$ activity by dietary HUFA, as described by Tocher (2003) and Zheng et al. (2005). Moreover, constant (CB1 and CB2) or decreasing (CTRL and CB3) fads6-a activities were observed during our 100-day trial that might be associated with lower $18: 3 n-3 / 18: 2 n-6$ ratios or excess LA or ALA (Izquierdo et al., 2008; Li et al., 2008). It is well known that the fads6 enzyme in fish has greater affinity with n-3 than n-6 FAs. However, substrates can also compete specifically with one another (Vagner and Santigosa, 2011).

Mechanisms behind fads6- $a$ activity regulation require further studies, however, could explain greater expression observed for CTRL and CB1 fed fish in comparison to those receiving CB2 and CB3. Interestingly, expression of elovl5- $a$, except in CB1 fish, was similar to fads6- $a$. Both genes are involved in HUFA biosynthesis, and increased elovl5- $a$ expression in CB1 fish is most likely linked to increased proportions of ALA, EPA and DHA in the feed. As shown for Atlantic salmon (Miller et al., 2008) and common carp var. Jian. (Ren et al., 2012), HUFA most likely reduced elovl5- $a$ activity through reduced promoter activity (Zheng et al., 2009). Ren et al. (2012) showed that expression of elovl5- $a$ and elovl5- $b$ were consistent, which is contrary to our findings, which suggest increased elovl5- $a$ activity in relation to CB1-3 feed compositions.

In CTRL and CB3 fish, FM and salmon oil HUFA down-regulated elovl5-a. In turn, HUFA, derived from the thraustochytrid microalga Schizochytrium sp. (CB1 and CB2), together with other algae meal components, stimulated expression of this gene. Differences in fads6- $a$ and elovl5- $a$ activities might result from the fact that many elovl5 elongase genes in fish species have been reported to prefer $\mathrm{C}_{18}$ and $\mathrm{C}_{20}$ PUFAs as substrates, with residual conversion toward $\mathrm{C}_{22}$ substrates (Monroig et al., 2012; Ren et al., 2012). Thus, reduced efficiency of elongation, $22: 5 n-3$ to $24: 5 n-3$, which is the substrate for $\Delta 6 \mathrm{D}$, would stabilize hepatic fads6- $a$ expression in CB1 carp, as demonstrated in this study. Comparisons of elovl5- $a$ and fas activities also support these dietary effects on fat metabolism, as described above.

The activity of fas gene increased in CB1 and CB2 fed fish (highest EPA/DHA) and increased feed FAs triggered a dose-dependent increase in hepatic fas mRNA. However, results for Atlantic salmon (Morais et al., 2011) and mammals (Davidson, 2006) indicated an inhibitory effect of HUFA on hepatic fas activity, leading to hypotriglyceridemia resulting from lipogenesis and enhanced fatty acid oxidation. In our study, fas expression was dependent on HUFA concentrations, as shown in large yellow croaker (Larmichthys crocea), where FM-enriched feed was associated with increased fas activity (Qiu et al., 2017). In contrast, Zhu (2005) found that expression of fas in grass carp (Ctenopharyngodon idella) muscle and liver was inhibited significantly by lard, and soybean and fish oils in the diet. Levels of fas activity also correlate with plasma TAG concentrations (Semenkovich, 1997), because encoded FAS enzyme catalyses synthesis of long chain FAs, mainly through acetyl coenzyme A and malonyl coenzyme A. We observed a link between fas activity and TAG in relation to the CB1 diet, which contained the most EPA/DHA. Analyses also revealed differences in fas expression were quality dependent, as the diets were isolipidic (8\% in all variants).

Expression of hepatic ppar- $\alpha$ increased over time in CB1 and CB2 fed carp. Lu et al. (2014) observed that feeding blunt snout bream with a 
high-fat diet decreased ppar- $\alpha$ expression and inhibited fat $\beta$-oxidation and steatosis. Higher hepatic ppar- $\alpha$ activities in CB1 and CB2 fed fish could be due to increased EPA and DHA concentrations in the feeds and/or additional SFAs and MUFAs, which are utilized preferentially during the $\beta$-oxidation (Kjær et al., 2008; Lu et al., 2014). Moreover, EPA induces mitochondrial proliferation and reduces intracellular lipid (Kjær et al., 2008). Hepatic ppar- $\alpha$ activity decreased in CTRL and CB3 fish, which might be explained by the increased content of plant-derived components (Ye et al., 2019) that down-regulated lipid metabolism-related gene expression, including carnitine palmitoyltransferase 1 (cpt1), apolipoprotein AI (apo-aI) and lipoprotein lipase (lpl). Further research is required to assess the mechanisms underlying ppar- $\alpha$ expression amongst the dietary groups in this study.

Activity of acox 1 , which determines $\beta$-oxidation capacity, was also dependent on qualitative fat compositions in the feeds. However, the dynamics of this gene's activities were different from those of ppar- $\alpha$ across all diets. Decreased acox1 expression was noted in CB1 fish (the highest EPA and DHA content), while in CTRL fish (the lowest EPA and DHA content) acox1 activity did not change. Previous studies have shown that feeds with higher proportions of n-3 FAs increased acox1 activity in rainbow trout (Figueiredo-Silva et al., 2012) but had no effect on Atlantic salmon (Caballero-Solares et al., 2018). Literature for lipid metabolism in common carp is sparse and, thus, further studies are needed to determine the mechanisms of action.

Dietary fat concentrations, as well as composition of the lipids, in feeds influence ectopic lipid accumulation in farmed fish tissues (liver, abdominal adipose tissue), which is often reflected in hepatocyte histomorphology (Caballero et al., 1999; Yan et al., 2015). Isolipidic feeds used in the experiment were not associated with any pathological (disease-related) changes in hepatocytes structure, suggesting the amounts of dietary lipid or energy provided did not exceed the capacity of hepatocytes to oxidise FAs. Differences in hepatocyte and/or nucleus size observed in our study concerned carp fed elevated amounts of EFA (CB1-2). However, a more informative indicator, elaborating on the dynamics of changes occurring in hepatocytes, was the N/C ratio (i.e. hepatocyte nucleus area to hepatocyte area). The highest ratio was found for CB1 and CB2 fed fish, indicating intensive metabolism, as confirmed by increased expression of fas and elovl5-a. Ye et al. (2019) showed that lower activities of genes involved in hepatic fat metabolism resulted in higher occurrences of hepatocyte vacuolisation and nuclear atrophy, disappearance or reduction, which are signs of nuclear pycnosis. Ostaszewska et al. (2005) showed the highest metabolic activity of rainbow trout hepatocytes in fish fed the control diet without extracted soybean meal or soybean protein concentrate.

Ultimately, the use of CB1 and CB2 feeds was reflected in carp fillet FA profiles. A similar relationship, between feed and fillet composition, has been shown for zebrafish (Danio rerio) muscle, where DHA increased as a result of a feed containing $50 \%$ of commercial ingredients and $50 \%$ freeze-dried marine microalga Schizochytrium sp. (Byreddy et al., 2019). Schultz et al. (2018) showed that common carp can almost triple n-3 PUFA contents after consuming a finishing diet containing FO for only 30 days. Schultz et al. (2018) demonstrated that FA profiles in finishing feeds were the most accurate predictors of dorsal fillet composition, specifically total lipid content, regardless of the source (e.g. natural pond zooplankton, terrestrial or marine), although carp fillets contained more lipids when supplied with marine feeds. In our study, the highest fat content (4.51\%) was observed in in fillets from CB3 fed fish, the only diet containing oil extracted from wild salmon by-products. Ahlgren et al. (1994) showed that SFA and MUFA (but not PUFA) concentrations were correlated with muscle fat contents, mainly because increasing total lipids in fish muscle is associated with storage lipids (TAG) rather than structural lipids (e.g. phospholipids). Moreover, amounts of phospholipids are influenced primarily by taxa-specific cell membrane requirements (Gause and Trushenski, 2013; Böhm et al., 2014) and farming conditions, e.g. temperature (Vagner and Santigosa, 2011, and references therein). Therefore, results described by Steffens and Wirth (2007) are potentially interesting, as they noted higher n-3 and n-6 FA concentrations in fillets from carp reared in extensive systems and fed natural feeds.

\section{Conclusion}

The present study demonstrates that different sources of dietary lipids can influence zootechnical parameters, regulate metabolic pathways at biochemical and transcriptional levels, and affect liver histology and muscle FA profiles in common carp. Considering the information available currently, in the near future, carp could contribute more as a source of n-3 PUFA in human nutrition. Carp has huge potential for sustainable aquaculture and, as identified in our study, the high phenotypic plasticity of carp can be exploited for fillets with beneficial nutrient compositions without impacting FBW. Understanding how dietary FA supplies are absorbed, retained and metabolised in common carp, and how FA profiles can be manipulated efficiently, requires further work but could unlock the full potential of an important fish farmed worldwide.

\section{CRediT authorship contribution statement}

P. Eljasik: Writing - review \& editing, Investigation, Visualization. R. Panicz: Conceptualization, Writing - review \& editing, Investigation. M. Sobczak: Writing - review \& editing, Supervision, Formal analysis. J. Sadowski: Resources. V. Barbosa: Writing - review \& editing. A. Marques: Writing - review \& editing. J. Dias: Resources.

\section{Declaration of competing interest}

The authors declare that they have no known competing financial interests or personal relationships that could have appeared to influence the work reported in this paper.

\section{Acknowledgements}

This research is part of the EU Horizon 2020 project SEAFOOD $^{\text {TOMORROW }}$. This project has received funding from the European Union's Horizon 2020 funding programme, Grant Agreement no. 773400 (SEAFOOD ${ }^{\text {TOMORROW }}$ ). This output reflects the views of the author(s), and the European Commission cannot be held responsible for any use that might be made of the information contained therein.

\section{References}

Ahlgren, G., Blomqvist, P., Boberg, M., Gustafsson, I., 1994. Fatty acid content of the dorsal muscle-an indicator of fat quality in freshwater fish. J. Fish. Biol. 45 (1), 131-157. https://doi.org/10.1111/j.1095-8649.1994.tb01292.x.

Allen, K.M., Habte-Tsion, H., Thompson, K.R., Filer, K., Tidwell, J.H., Kumar, V., 2019. Freshwater microalgae (Schizochytrium sp.) as a substitute to fish oil for shrimp feed. Sci. Rep. 9 (1), 6178. https://doi.org/10.1038/s41598-019-41020-8.

Anon, 2012. Guidelines for the treatment of animals in behavioural research and teaching. Anim. Behav. 83 (1), 301-309. https://doi.org/10.1016/j.anbehav.2011. 10.031 .

Araújo, B.C., Mata-Sotres, J.A., Viana, M.T., Tinajero, A., Braga, A., 2019. Fish oil-free diets for Pacific white shrimp Litopenaeus vannamei: the effects of DHA-EPA supplementation on juvenile growth performance and muscle fatty acid profile. Aquaculture 511, 734276. https://doi.org/10.1016/j.aquaculture.2019.734276.

Arts, M.T., Kohler, C.C., 2009. Health and condition in fish: the influence of lipids on membrane competency and immune response. In: Arts, M.T., Brett, M.T., Kainz, M.J. (Eds.), Lipids in Aquatic Ecosystems, pp. 237-256. https://doi.org/10.1007/978-0387-89366-2_10. New York.

Bell, J.G., Tocher, D.R., Henderson, R.J., Dick, J.R., Crampton, V.O., 2003. Altered fatty acid compositions in Atlantic salmon (Salmo salar) fed diets containing linseed and rapeseed oils can be partially restored by a subsequent fish oil finishing diet. J. Nutr. 133 (9), 2793-2801. https://doi.org/10.1093/jn/133.9.2793.

Bell, M.V., Dick, J.R., Porter, A.E.A., 2001. Biosynthesis and tissue deposition of docosahexaenoic acid (22: $6 \mathrm{n}-3$ ) in rainbow trout (Oncorhynchus mykiss). Lipids 36 (10), 1153-1159. https://doi.org/10.1007/s11745-001-0826-1.

Berntssen, M.H., Betancor, M., Caballero, M.J., Hillestad, M., Rasinger, J., Hamre, K., Sale, V., Amlund, H., Ørnsrud, R., 2018. Safe limits of selenomethionine and selenite 
supplementation to plant-based Atlantic salmon feeds. Aquaculture 495, 617-630. https://doi.org/10.1016/j.aquaculture.2018.06.041.

Bickley, L.K., Lange, A., Winter, M.J., Tyler, C.R., 2009. Evaluation of a carp primary hepatocyte culture system for screening chemicals for oestrogenic activity. Aquat. Toxicol. 94, 195-203. https://doi.org/10.1016/j.aquatox.2009.07.006.

Böhm, M., Schultz, S., Koussoroplis, A.M., Kainz, M.J., 2014. Tissue-specific fatty acids response to different diets in common carp (Cyprinus carpio L.). PloS One 9 (4), e94759. https://doi.org/10.1371/journal.pone.0094759.

Burck, H.C., 1975. Utrwalanie. Technika Histologiczna. [Fixation. Histological Technique.]. PZWL, Warsaw, pp. 62-63 ([In Polish]).

Byreddy, A.R., Yoganantharjah, P., Gupta, A., Gibert, Y., Puri, M., 2019. Suitability of novel algal biomass as fish feed: accumulation and distribution of omega-3 long-chain polyunsaturated fatty acid in zebrafish. Appl. Biochem. Biotechnol. 188 (1), 112-123. https://doi.org/10.1007/s12010-018-2906-0.

Caballero-Solares, A., Xue, X., Parrish, C.C., Foroutani, M.B., Taylor, R.G., Rise, M.L., 2018. Changes in the liver transcriptome of farmed Atlantic salmon (Salmo salar) fed experimental diets based on terrestrial alternatives to fish meal and fish oil. BMC Genom. 19 (1), 796. https://doi.org/10.1186/s12864-018-5188-6.

Caballero, M.J., López-Calero, G., Socorro, J., Roo, F.J., Izquierdo, M.S., Férnandez, A.J., 1999. Combined effect of lipid level and fish meal quality on liver histology of gilthead seabream (Sparus aurata). Aquaculture 179 (1-4), 277-290. https://doi.org/10. 1016/S0044-8486(99)00165-9.

Corcoran, J., Winter, M.J., Lange, A., Cumming, R., Owen, S.F., Tyler, C.R., 2015. Effects of the lipid regulating drug clofibric acid on PPAR $\alpha$-regulated gene transcript levels in common carp (Cyprinus carpio) at pharmacological and environmental exposure levels. Aquat. Toxicol. 161, 127-137. https://doi.org/10.1016/j.aquatox.2015.01. 033

Csengeri, I., Čolović, D., Rónyai, A., Jovanović, R., Péter-Szúcsné, J., Sándor, Z., Gyimes, E., 2013. Feeding of common carp on floating feeds for enrichment of fish flesh with essential fatty acids. Food Feed Res. 40 (2), 59-70.

Davidson, M.H., 2006. Mechanisms for the hypotriglyceridemic effect of marine omega-3 fatty acids. Am. J. Cardiol. 98 (4), 27-33. https://doi.org/10.1016/j.amjcard.2005. 12.024.

Deng, J., Mai, K., Ai, Q., Zhang, W., Wang, X., Tan, B., Xu, W., Liufu, Z., Ma, H., 2010. Interactive effects of dietary cholesterol and protein sources on growth performance and cholesterol metabolism of Japanese flounder (Paralichthys olivaceus). Aquacult. Nutr. 16 (4), 419-429. https://doi.org/10.1111/j.1365-2095.2009.00681.x.

Du, Z.Y., Liu, Y.J., Tian, L.X., Wang, J.T., Wang, Y., Liang, G.Y., 2005. Effect of dietary lipid level on growth, feed utilization and body composition by juvenile grass carp (Ctenopharyngodon idella). Aquacult. Nutr. 11 (2), 139-146. https://doi.org/10.1111/ j.1365-2095.2004.00333.x.

EFSA, 2014. Panel on Dietetic Products, Nutrition and Allergies (NDA); Scientific Opinion on health benefits of seafood (fish and shellfish) consumption in relation to health risks associated with exposure to methylmercury. EFSA J. 12 (7), 3761. 2014. https://doi:10.2903/j.efsa.2014.3761 80

Fedorova-Dahms, I., Marone, P.A., Bauter, M., Ryan, A.S., 2011. Safety evaluation of DHA-rich algal oil from Schizochytrium sp. Food Chem. Toxicol. 49, 3310-3318. https://doi.org/10.1016/j.fct.2011.08.024.

Figueiredo-Silva, A.C., Kaushik, S., Terrier, F., Schrama, J.W., Médale, F., Geurden, I., 2012. Link between lipid metabolism and voluntary food intake in rainbow trout fed coconut oil rich in medium-chain TAG. Br. J. Nutr. 107 (11), 1714-1725. https://doi. org/10.1017/S0007114511004739.

Gause, B.R., Trushenski, J.T., 2013. Sparing fish oil with beef tallow in feeds for rainbow trout: effects of inclusion rates and finishing on production performance and tissue fatty acid composition. N. Am. J. Aquacult. 75, 495-511. https://doi.org/10.1080/ 15222055.2013.811134.

Gonzalez, S.F., Huising, M.O., Stakauskas, R., Forlenza, M., Verburg-van Kemenade, B.L., Buchmann, K., Nielsen, M., Wiegertjes, G.F., 2007. Real-time gene expression analysis in carp (Cyprinus carpio L.) skin: inflammatory responses to injury mimicking infection with ectoparasites. Dev. Comp. Immunol. 31 (3), 244-254. https://doi.org/ 10.1016/j.dci.2006.06.010.

Huang, J.F., Xu, Q.Y., Chang, Y.M., 2015. Effects of temperature and dietary protein on gene expression of Hsp 70 and Wap65 and immunity of juvenile mirror carp (Cyprinus carpio). Aquacult. Res. 46, 2776-2788. https://doi.org/10.1111/are.12432.

Innis, S.M., 2007. Dietary (n-3) fatty acids and brain development. J. Nutr. 137 (4), 855-859. https://doi.org/10.1093/jn/137.4.855.

Izquierdo, M.S., Robaina, L., Juárez-Carrillo, E., Oliva, V., Hernández-Cruz, C.M., Afonso, J.M., 2008. Regulation of growth, fatty acid composition and delta 6 desaturase expression by dietary lipids in gilthead seabream larvae (Sparus aurata). Fish Physiol. Biochem. 34 (2), 117-127. https://doi.org/10.1007/s10695-007-9152-7.

Jin, M., Monroig, Ó., Lu, Y., Yuan, Y., Li, Y., Ding, L., Tocher, D., Zhou, Q., 2017. Dietary DHA/EPA ratio affected tissue fatty acid profiles, antioxidant capacity, hematological characteristics and expression of lipid-related genes but not growth in juvenile black seabream (Acanthopagrus schlegelii). PloS One 12 (4), e0176216. https://doi.org/10. 1371/journal.pone.0176216.

Jordal, A.E., Lie, Ø., Torstensen, B.E., 2007. Complete replacement of dietary fish oil with a vegetable oil blend affect liver lipid and plasma lipoprotein levels in Atlantic salmon (Salmo salar L.). Aquacult. Nutr. 13 (2), 114-130. https://doi.org/10.1111/j. 1365-2095.2007.00455.x.

Kjær, M.A., Vegusdal, A., Gjøen, T., Rustan, A.C., Todorčević, M., Ruyter, B., 2008. Effect of rapeseed oil and dietary n-3 fatty acids on triacylglycerol synthesis and secretion in Atlantic salmon hepatocytes. BBA-Mol. Cell. Biol. L. 1781 (3), 112-122. https://doi. org/10.1016/j.bbalip.2007.12.004.

Leaver, M.J., Villeneuve, L.A., Obach, A., Jensen, L., Bron, J.E., Tocher, D.R., Taggart, J.B., 2008. Functional genomics reveals increases in cholesterol biosynthetic genes and highly unsaturated fatty acid biosynthesis after dietary substitution of fish oil with vegetable oils in Atlantic salmon (Salmo salar). BMC Genom. 9 (1), 299. https:// doi.org/10.1186/1471-2164-9-299.

Lemaire, P., Drai, P., Mathieu, A., Lemaire, S., Carriere, S., Giudicelli, J., Lafaurie, M., 1991. Changes with different diets in plasma enzymes (GOT, GPT, LDH, ALP) and plasma lipids (cholesterol, triglycerides) of sea-bass (Dicentrarchus labrax). Aquaculture 93 (1), 63-75. https://doi.org/10.1016/0044-8486(91)90205-L.

Li, Y., Hu, C., Zheng, Y., Xia, X., Xu, W., Wang, S., Chen, W., Sun, Z., Huang, J., 2008. The effects of dietary fatty acids on liver fatty acid composition and $\Delta 6$-desaturase expression differ with ambient salinities in Siganus canaliculatus. Comp. Biochem. Physiol. B Biochem. Mol. Biol. 151 (2), 183-190. https://doi.org/10.1016/j.cbpb. 2008.06.013.

Liu, J., Ma, D., 2014. The role of n-3 polyunsaturated fatty acids in the prevention and treatment of breast cancer. Nutrients 6 (11), 5184-5223. https://doi.org/10.3390/ nu6115184.

Lu, K.L., Xu, W.N., Li, X.F., Liu, W.B., Wang, L.N., Zhang, C.N., 2013. Hepatic triacylglycerol secretion, lipid transport and tissue lipid uptake in blunt snout bream (Megalobrama amblycephala) fed high-fat diet. Aquaculture 408, 160-168. https:// doi.org/10.1016/j.aquaculture.2013.06.003.

Lu, K.L., Xu, W.N., Wang, L.N., Zhang, D.D., Zhang, C.N., Liu, W.B., 2014. Hepatic $\beta$ oxidation and regulation of carnitine palmitoyltransferase (CPT) I in blunt snout bream Megalobrama amblycephala fed a high fat diet. PloS One 9 (3), e93135. https:// doi.org/10.1371/journal.pone.0093135.

Miller, M.R., Bridle, A.R., Nichols, P.D., Carter, C.G., 2008. Increased elongase and desaturase gene expression with stearidonic acid enriched diet does not enhance longchain (n-3) content of seawater Atlantic salmon (Salmo salar L.). J. Nutr. 138 (11), 2179-2185. https://doi.org/10.3945/jn.108.091702.

Monroig, Ó., Wang, S., Zhang, L., You, C., Tocher, D.R., Li, Y., 2012. Elongation of longchain fatty acids in rabbitfish Siganus canaliculatus: cloning, functional characterisation and tissue distribution of Elovl5-and Elovl4-like elongases. Aquaculture 350, 63-70. https://doi.org/10.1016/j.aquaculture.2012.04.017.

Morais, S., Pratoomyot, J., Taggart, J.B., Bron, J.E., Guy, D.R., Bell, J.G., Tocher, D.R., 2011. Genotype-specific responses in Atlantic salmon (Salmo salar) subject to dietary fish oil replacement by vegetable oil: a liver transcriptomic analysis. BMC Genom. 12 (1), 255. https://doi.org/10.1186/1471-2164-12-255.

Nasir, N.A., Al-Sraji, A.Y.J., 2013. Effect of different dietary protein and fats on some biochemical blood parameters in common carp fingerlings (Cyprinus carpio L.) reared in float cages. Asian. J. Exp. 4, 293-296.

Ostaszewska, T., Dabrowski, K., Palacios, M.E., Olejniczak, M., Wieczorek, M., 2005. Growth and morphological changes in the digestive tract of rainbow trout (Oncorhynchus mykiss) and pacu (Piaractus mesopotamicus) due to casein replacement with soybean proteins. Aquaculture 245 (1-4), 273-286. https://doi.org/10.1016/j. aquaculture.2004.12.005.

SO 12966-1:2015-01. Oleje I Tłuszcze Roślinne Oraz Zwierzęce - Chromatografia Gazowa Estrów Metylowych Kwasów Tłuszczowych.

Özlüer Hunt, A., Özkan Yilmaz, Z., Erçen, Z., 2018. Comparing the effects of feeding a fish oil- or a cod liver oil -based diet on growth, feed utilization and muscle fatty acid composition Nile tilapia (Oreochromis niloticus). Mediterr. Fish. Aquacult. Res. 1 (3), 130-142.

Poleksić, V., Stanković, M., Marković, Z., Relić, R., Lakić, N., Dulić, Z., Rašković, B., 2014. Morphological and physiological evaluation of common carp (Cyprinus carpio L., 1758) fed extruded compound feeds containing different fat levels. Aquacult. Int. 22 (1), 289-298. https://doi.org/10.1007/s10499-013-9654-5.

Qiu, H., Jin, M., Li, Y., Lu, Y., Hou, Y., Zhou, Q., 2017. Dietary lipid sources influence fatty acid composition in tissue of large yellow croaker (Larmichthys crocea) by regulating triacylglycerol synthesis and catabolism at the transcriptional level. PloS One 12 (1), e0169985. https://doi.org/10.1371/journal.pone.0169985.

Ren, H.T., Yu, J.H., Xu, P., Tang, Y.K., 2012. Influence of dietary fatty acids on muscle fatty acid composition and expression levels of $\Delta 6$ desaturase-like and Elovl5-like elongase in common carp (Cyprinus carpio var. Jian). Comp. Biochem. Physiol. B Biochem. Mol. Biol. 163 (2), 184-192. https://doi.org/10.1016/j.cbpb.2012.05.016.

Richard, N., Kaushik, S., Larroquet, L., Panserat, S., Corraze, G., 2006a. Replacing dietary fish oil by vegetable oils has little effect on lipogenesis, lipid transport and tissue lipid uptake in rainbow trout (Oncorhynchus mykiss). Br. J. Nutr. 96 (2), 299-309. https:// doi.org/10.1079/BJN20061821.

Richard, N., Mourente, G., Kaushik, S., Corraze, G., 2006b. Replacement of a large portion of fish oil by vegetable oils does not affect lipogenesis, lipid transport and tissue lipid uptake in European seabass (Dicentrarchus labrax L.). Aquaculture 261 (3), 1077-1087. https://doi.org/10.1016/j.aquaculture.2006.07.021.

Romarheim, O.H., Skrede, A., Gao, Y., Krogdahl, Å., Denstadli, V., Lilleeng, E., Storebakken, T., 2006. Comparison of white flakes and toasted soybean meal partly replacing fish meal as protein source in extruded feed for rainbow trout (Oncorhynchus mykiss). Aquaculture 256 (1-4), 354-364. https://doi.org/10.1016/j. aquaculture.2006.02.006.

Sargent, J.R., Tocher, D.R., Bell, J.G., 2002. The lipids. In: Halver, J.E., Hardy, R.W. (Eds.), Fish Nutrition, pp. 194-201 London.

Schultz, S., Koussoroplis, A.M., Kainz, M.J., 2018. Dietary fatty-acid compositions are more strongly reflected in fatty than lean dorsal fillets of common carp (Cyprinus carpio L.). Lipids 53 (7), 727-735. https://doi.org/10.1002/lipd.12080.

Semenkovich, C.F., 1997. Regulation of fatty acid synthase (FAS). Prog. Lipid Res. 36 (1), 43-53. https://doi.org/10.1016/S0163-7827(97)00003-9.

Sioen, I., van Lieshout, L., Eilander, A., Fleith, M., Lohner, S., Szommer, A., Petisca, C., Eussen, S., Forsyth, S., Calder, P.C., Campoy, C., Mensink, R.P., 2017. Systematic review on n-3 and n- 6 polyunsaturated fatty acid intake in European countries in light of the current recommendations-Focus on specific population groups. Ann. Nutr. Metab. 70 (1), 39-50. https://doi.org/10.1159/000456723.

Sissener, N.H., 2018. Are we what we eat? Changes to the feed fatty acid composition of 
farmed salmon and its effects through the food chain. J. Exp. Biol. 221 (Suppl. 1), jeb161521. https://doi.org/10.1242/jeb.161521.

Steffens, W., Wirth, M., 2007. Influence of nutrition on the lipid quality of pond fish: common carp (Cyprinus carpio) and tench (Tinca tinca). Aquacult. Int. 15 (3-4), 313-319. https://doi.org/10.1007/s10499-007-9088-Z.

Tang, Y.K., Yu, J.H., Xu, P., Li, J.L., Li, H.X., Ren, H.T., 2012. Identification of housekeeping genes suitable for gene expression analysis in Jian carp (Cyprinus carpio var. jian). Fish Shellfish Immunol. 33 (4), 775-779. https://doi.org/10.1016/j.fsi.2012. 06.027.

Tocher, D.R., 2003. Metabolism and functions of lipids and fatty acids in teleost fish. Rev. Fish. Sci. 11 (2), 107-184. https://doi.org/10.1080/713610925.

Tocher, D.R., Betancor, M.B., Sprague, M., Olsen, R.E., Napier, J.A., 2019. Omega-3 longchain polyunsaturated fatty acids, EPA and DHA: bridging the gap between supply and demand. Nutrients 11 (1), 89. https://doi.org/10.3390/nu11010089.

Torstensen, B.E., Espe, M., Stubhaug, I., Lie, Ø., 2011. Dietary plant proteins and vegetable oil blends increase adiposity and plasma lipids in Atlantic salmon (Salmo salar L.). Br. J. Nutr. 106 (5), 633-647. https://doi.org/10.1017/S0007114511000729.

Twibell, R.G., Wilson, R.P., 2004. Preliminary evidence that cholesterol improves growth and feed intake of soybean meal-based diets in aquaria studies with juvenile channel catfish, Ictalurus punctatus. Aquaculture 236 (1-4), 539-546. https://doi.org/10. 1016/j.aquaculture.2003.10.028.

Vagner, M., Santigosa, E., 2011. Characterization and modulation of gene expression and enzymatic activity of delta- 6 desaturase in teleosts: a review. Aquaculture 315 (1-2), 131-143. https://doi.org/10.1016/j.aquaculture.2010.11.031.

Van der Spiegel, M., Noordam, M.Y., Van der Fels-Klerx, H.J., 2013. Safety of novel protein sources (insects, microalgae, seaweed, duckweed, and rapeseed) and legislative aspects for their application in food and feed production. Compr. Rev. Food Sci. Food Saf. 12 (6), 662-678. https://doi.org/10.1111/1541-4337.12032.

Williams, M.C.W, Murphy, E.W, McCarty, H.B., Snyder, B.D., Schrank, C.S., McCann, P.J., Crimmins, B.S., 2017. Variation in the essential fatty acids EPA and DHA in fillets of fish from the Great Lakes region. J. Great Lake. Res. 43 (3), 150-160. https://doi.org/ 10.1016/j.jglr.2017.03.001.

Xu, P., Zhang, X., Wang, X., Li, J., Liu, G., Kuang, Y., Xu, J., Zheng, X., Ren, L., Wang, G.,
Zhang, Y., Huo, L., Zhao, Z., Cao, D., Lu, C., Li, C., Zhou, Y., Liu, Z., Fan, Z., Shan, G., Li, X., Wu, S., Song, L., Hou, G., Jiang, Y., Jeney, Z., Yu, D., Wang, L., Shao, C., Song, L., Sun, J., Ji, P., Wang, J., Li, Q., Xu, L., Sun, F., Feng, J., Wang, C., Wang, S., Wang, B., Li, Y., Zhu, Y., Xue, W., Zhao, L., Wang, J., Gu, Y., Lv, W., Wu, K., Xiao, J., Wu, J., Zhang, Z., Yu, J., Sun, X., 2014. Genome sequence and genetic diversity of the common carp, Cyprinus carpio. Nat. Genet. 46, 1212-1219. https://doi.org/10.1038/ ng.3098.

Yan, J., Liao, K., Wang, T., Mai, K., Xu, W., Ai, Q., 2015. Dietary lipid levels influence lipid deposition in the liver of large yellow croaker (Larimichthys crocea) by regulating lipoprotein receptors, fatty acid uptake and triacylglycerol synthesis and catabolism at the transcriptional level. PloS One 10 (6), e0129937. https://doi.org/10.1371/ journal.pone.0129937.

Ye, H., Xu, M., Chen, L., Tan, X., Chen, S., Zou, C., Sun, Z., Liu, Q., Ye, C., Wang, A., 2019. Effects of dietary plant protein sources influencing hepatic lipid metabolism and hepatocyte apoptosis in hybrid grouper (Epinephelus lanceolatus $\sigma^{\prime} \times$ Epinephelus fuscoguttatus P). Aquaculture 506, 437-444. https://doi.org/10.1016/j.aquaculture. 2019.03.075.

Zhang, X., Pang, S., Liu, C., Wang, H., Ye, D., Zhu, Z., Sun, Y., 2019. A novel dietary source of EPA and DHA: metabolic engineering of an important freshwater species-common carp by fat1-transgenesis. Mar. Biotechnol. 21 (2), 171-185. https:// doi.org/10.1007/s10126-018-9868-7.

Zheng, X., Leaver, M.J., Tocher, D.R., 2009. Long-chain polyunsaturated fatty acid synthesis in fish: comparative analysis of Atlantic salmon (Salmo salar L.) and Atlantic cod (Gadus morhua L.) $\Delta 6$ fatty acyl desaturase gene promoters. Comp. Biochem. Physiol. B Biochem. Mol. Biol. 154 (3), 255-263. https://doi.org/10.1016/j.cbpb. 2009.06.010.

Zheng, X., Tocher, D.R., Dickson, C.A., Bell, J.G., Teale, A.J., 2005. Highly unsaturated fatty acid synthesis in vertebrates: new insights with the cloning and characterization of a $\Delta 6$-desaturase of Atlantic salmon. Lipids 40, 13-24. https://doi.org/10.1007/ s11745-005-1355-7.

Zhu, D.S., 2005. Effects of Staruation and Different Dietary Lipid on Fat Content and Fatty Acid Synthetase of Grass Carp(Ctenopharyngodon Idella). Thesis for Master of Science. Huazhong Agricultural University, Wuhan, China. 